\title{
Problem of domestic violence: international scope and national perspectives on legislative resolution
}

\author{
Elena Genrikhovna Komissarova ${ }^{1^{*}}$, Tatyana Vladimirovna Krasnova ${ }^{2}$, Svetlana Viktorovna \\ Zimneva $^{2}$, Natalia Valeryevna Gorina ${ }^{2}$, and Tamara Vasilyevna Shershen ${ }^{1}$ \\ ${ }^{1}$ Perm State National Research University, Department of Civil Law, Perm, Russia \\ ${ }^{2}$ Tyumen State University, Department of Civil Law and Procedure, Tyumen, Russia
}

\begin{abstract}
The authors seek to form a theoretical basis for the Russian legislator creating legislation against domestic violence by comparing the theoretical and legislative ideas implemented in different countries in creating such special legislation. The purpose of the study is to analyze the Russian theoretical resource on the problem of intrafamily violence to identify the "missing links" in the doctrinal study of the problem and dogmatic qualification of relations arising in such violence. In an attempt to change the existing trajectory of this type of substantive research, the authors address domestic violence prevention using interdisciplinary and systemic approaches involving the methods of analysis, generalization, formal logic, hermeneutics, and comparison. Based on the study results, the authors conclude that conceptual problems of domestic violence do not fit into the thematic framework of family law science. To develop an adequate law concept on the prevention of domestic violence and the protection of its victims, the system of source studies must include not only the views of representatives of family law science but also the surrounding sciences.

Keywords: domestic violence, prevention, protection of victims
\end{abstract}

\section{Introduction}

Special legislation on preventing domestic violence and its victims' protection is new for the Russian legal system. Science is actively exploring it. However, despite the large-scale theoretical attention to the problem, a full-scale theoretical foundation that would interest the legislator has not been created. The draft laws submitted to the State Duma of the Federal Assembly of the Russian Federation in 1996 [1] and 1997 [2] were not supported by the legislator. The third draft law No. 1183390-6 "On the prevention of domestic violence" [3], created in 2016 with the help of the manual for the development of legislation on violence against women, prepared within the framework of the United Nations [4], also did not become law. Another legislative attempt made in 2019 [5], although it caused a significant public outcry, remained unrealized. As stated in one of the European Court of Human Rights

* Corresponding author: eg-komissarova@yandex.ru 
resolutions, so far, "Russian legislation in principle is not adapted to the protection of victims of domestic violence - not only physical but also psychological and economical" [6].

It is time to ask why most foreign legislations today record the statistics of the facts of domestic violence and report the facts of the reduction of its cases concerning special legislation, and national strategies in this matter do not reach the stage of being drafted.

\section{Results and discussion}

The whole history of human development is nothing but the development of civilization. As Samuel Huntington points out in his work The Clash of Civilizations, "civilization is the highest cultural community of people and the widest level of cultural identification, in addition to what distinguishes humans from other biological species" [7]. The family certainly belongs to the civilizational social institutions. The membership of this personal union in civilization's institutions defines its basic features as a union based on mutual love, respect, support, respect for the norms of morality, and the ability to agree in disagreements. Otherwise, it shows the shortcomings of this social institution, contributes to the erosion of the norms on which the normative basis of everyday life is based [8].

As stated in a foreign science that studies the legal problems of domestic violence, "in the twenty-first century, domestic violence continues to be one of the most misunderstood crimes" [9]. Many countries seek to correct this shortcoming through special legislation. Russia is no exception. However, one should not discount the fact that this law is truly revolutionary for Russia. Relying on a very brief and non-systematic experience of supporting domestic violence victims through virtual-remote interaction, focused on anonymity (helpline in the Ministry of Internal Affairs of Russia, emergency psychological assistance) is insufficient. The experience of the regional crisis centers that came to the Russian reality in 1993 is undoubtedly significant, but unlike the functions of foreign centers of intervention, their functions in family affairs are limited. In countries that have adopted special legislation on domestic violence, the functions of these centers are quite broad, and they go into interdepartmental interaction. They assess the risk of a particular case of domestic violence; provide support and assistance in planning the safety of the victim and any dependent persons; provide legal advice and support to them in state bodies and courts; assist in the social welfare of victims of violence, their psychological and medical rehabilitation; provide shelter to women and suffering children [10].

It seems that national jurisprudence should make its contribution to the formation of the concept of special legislation. However, as the available research on the problem shows, so far, only the initial political solution is clear, based on the understanding that the victims of such violence need not only situational protection by administrative and depersonalized criminal law norms but also special civil protection measures and their further support to avoid subsequent recidivism. Yet, the scientific format of the research undertaken has not given this idea the viability it deserves.

The family is the center of interpersonal relationships, the very ones in which, as a general rule, there is no place for outsiders. However, there is always a centralized state force next to the family in the modern world, as the force that idealizes the family, relies on the moral resources of intra-family regulation, and does not seek hegemony in regulating this sphere. The problem of the measure of this force, the balance between privacy and the common good, the specifics of the legal regulation of interpersonal relations - these are the general theoretical problems without which it is impossible to create a high-quality and workable law that invades the private sphere in the name of the public. What are interpersonal relations for the law, in which it is challenging to fix the line that separates the private (love, mutual support) and the non-private (conflict with the use of any violence), what is the methodology of their legal regulation - the question in Russian legal science is still more unknown. 
Research on this topic is calculated in units [11-13] and cannot yet provide the necessary theoretical basis for the legislator.

Domestic violence is not a single branch and cannot be studied only in the bosom of family law science. At a minimum, it is necessary to look back at the achievements of civil law in studying subjective personal rights with their absolute nature. This theory, which focuses on the protection of personal rights, such as life, health, respect for the dignity of the individual, the free development of the individual, the right to privacy and its inviolability, etc., is not exclusively an intra-industry achievement, referring to all types of absolute rights "as subjective rights belonging to the individual as natural rights" [14]. In foreign science, there is more than one judgment that special legislation on preventing domestic violence is not entirely self-sufficient, having a close connection with civil tort law. In some countries, the "tort of domestic violence" [9] is included in the provisions of special laws on domestic violence.

It is also impossible to ignore the fact that modern foreign theories focused on the prevention of domestic violence and the healing of its victims are based on the expanded doctrine of human rights, which is recognized as absolutely incompatible with the "toxic picture of domestic violence within the family" [15]. This perspective lacks national studies, which are dominated by "sad" statistics on such violence and passive references to lists of international legal instruments recognizing domestic violence as illegitimate.

The Russian doctrine is also silent about the signals transmitted by foreign science about weak points and inconclusive legislative decisions revealed in the legislation on family and domestic violence. These include increased procedural requirements for civil remedies against domestic violence that hinder the effectiveness of this remedy [16], the duration of protective measures applied to the victim in the form of protective orders that must be longterm or even permanent [17]; otherwise, there is a risk of "causing even more harm to the victim in the long term" [18], the need to criminalize this type of domestic violence as forced control over the victim [19], the removal of law enforcement barriers in the service and enforcement of restraining orders [20].

Russian doctrine also passes over those innovations that are studied to the legislation on domestic violence. So, along with the already known points of this problem, the foreign doctrine also reflects new aspects in its study due to the increase in the number of types of domestic violence, where, along with the usual forms (physical, psychological, emotional, sexual), economic and financial violence is studied [21]. The foreign doctrine refers to them as new strategies for protecting the idea of economic justice. In the Russian doctrine, these types of violence are distinguished and studied [22, 23], but they were not included in any draft law. The provision of foreign legislation, according to which a child, in whose presence violence was committed, has the right to appeal to the court with a claim of recklessness, negligence, or premeditation of the parent who committed the violence, is also very relevant for the doctrinal assessment [24].

In a rational analysis of the Russian reality and the draft failed laws on domestic violence, it should be recognized that there are no necessary prerequisites for adopting a viable Russian law, except that "there must be a law". At a minimum, it is necessary to "detach" from the legal consciousness of Russians the idea of absolute intra-family immunity, which retains its power due to common expressions that belong on the shelf of national folklore: "lovers' quarrels are soon mended" or "beating husband is a loving husband". Outbreaks of such ideology are now found in foreign science, where occasionally very uncivilized judgments are recorded that "issues of domestic violence are a purely private matter of its members" [25], but they are not ubiquitous.

\section{Conclusion}


Based on the national theoretical discourse results, the authors of the article are forced to conclude that the degree of academic research of the problem remains shallow and incomplete. Empirical knowledge based on statistical data is sufficient; theoretically, objective knowledge is hugely lacking. For the most part, scientific works are permanent due to isolation from sociological and psychological studies that thoroughly investigated the realities of domestic violence and separation from the general legal theory, the science of civil and administrative law. The achievements and shortcomings identified in foreign legislation are also not taken into account.

\section{References}

1. Zakonoproekt No. 96700121-2 "O predotvrashchenii nasiliya v seme" [Draft Federal Law No. 96700121-2 "On the prevention of domestic violence"] (1996). Accessed on: November 16, 2020. [Online]. Available: https://sozd.duma.gov.ru/bill/96700121-2

2. Zakonoproekt No. 97700685-2 "Ob osnovakh sotsialno-pravovoi zashchity ot nasiliya v seme" [Draft Federal Law No. 97700685-2 "On the basics of social and legal protection from domestic violence"] (1997). Accessed on: November 16, 2020. [Online]. Available: https://sozd.duma.gov.ru/bill/97700685-2

3. Zakonoproekt No. 1183390-6 "O profilaktike semeino-bytovogo nasiliya” [[Draft Federal Law No. 1183390-6 "On the prevention of domestic violence"] (2016). Accessed on: November 16, 2020. [Online]. Available: https://sozd.duma.gov.ru/bill/1183390-6

4. United Nations, Handbook for Legislation on Violence against Women (United Nations, New York, 2010). Accessed on: November 16, 2020. [Online]. Available: https://www.un.org/womenwatch/daw/vaw/handbook/Handbook\%20for\%20legislation $\% 20$ on\%20violence\%20against\%20women.pdf

5. Zakonoproekt "O profilaktike semeino-bytovogo nasiliya v Rossiiskoi Federatsii" [Draft Federal Law "On the prevention of family and domestic violence in the Russian Federation"] (2019) Accessed on: November 16, 2020. [Online]. Available: http://council.gov.ru/media/files/rDb1bpYASUAxolgmPXEfKLUIq7JAARUS.pdf

6. European Court of Human Rights, Resolution in the case of "Volodina against Russia": complaint No. 41261/17 (2019, July 9): Accessed on: November 16, 2020. [Online]. Available: http://hudoc.echr.coe.int/eng?i=002-12549

7. S.P. Huntington, The clash of civilizations and the remaking of world order (Simon \& Schuster, New York, 2006)

8. A. Ellison, The impact of domestic violence on our community (2015). Accessed on: March 17, 2021. [Online]. Available: https://www.tnpsocal.org/the-impact-ofdomestic-violence-on-our-community

9. A. Paredes, D. Roberts, L. Ruvo, T. Stuart, Georgetown J. Gend. Law 19, 266 (2018)

10. D. Patterson, Journal of Interpersonal Violence. 26, 328-347 (2010)

11. I.A. Kanina, Chastnaya zhizn v sfere prava [Private life in the sphere of law]. $\mathrm{PhD}$ thesis (Derzhavin Tambov State University, Tambov, 2006)

12. R.B. Golovkin, A.M. Anisimova, Pravovoe vozdeistvie na otnosheniya blizkikh lits: Monografiya [Legal impact on relations of close persons: Monograph] (Vladimir Law Institute, Vladimir, 2006)

13. A.A. Demichev, Journal of Nizhny Novgorod Academy of the Ministry of Internal Affairs of Russia, 2(38), 23-27 (2017) 
14. A.Kh. Ulbashev, Zakonodatelstvo, 8, 8-13 (2017)

15. M.L. Breger, J. Legis 44(2), 170 (2017)

16. J.K. Stoever, Wash Law Rev. 94(1), 335 (2019)

17. J.K. Stoever, Vand. Law Rev. 67, 1015 (2014)

18. A. Bridgett, Health Matrix 30(1), 437 (2020)

19. O.A. Hess, Ind. Int. Comp. Law Rev. 30(3), 383 (2020)

20. K. Ballou, Notre Dame J. Law Ethics Public Policy, 31(2), 355 (2017)

21. D.M. Weissman, Utah Law Rev. 2020(1) (2020)

22. N.A. Pleshkova, Semeinoe nasilie i puti ego preodoleniya v sovremennom rossiiskom obshchestve: regionalnyi aspekt [Family violence and ways to overcome it in modern Russian society: regional aspect]. PhD thesis (Penza State University, Penza, 2017)

23. S.Ya. Salamova, Lex russika, 9(142), 129-138 (2018). https://doi.org/10.17803/17295920.2018.142.9.129-138

24. C. Carey, U. Kan. L. Rev. 62(3), 695-758 (2014)

25. Z. Medarić, Revija za socijalnu politiku, 18(1), 25-45 (2011) 